\title{
TRIBOLOGICAL PROPERTIES OF OXIDE COATINGS PRODUCED ON EN AW-5251 ALLOY USING DIFFERENT DISTANCES BETWEEN ELECTRODES
}

doi: 10.2478/cqpi-2019-0054

Date of submission of the article to the Editor: $01 / 04 / 2019$

Date of acceptance of the article by the Editor: 28/05/2019

Marek Bara ${ }^{1}$ - orcid id: 0000-0002-3488-759X

Renata Dwornicka ${ }^{2}$ - orcid id: 0000-0002-2979-1614

1 University of Silesia, Faculty of Computer and Materials Science, Poland

${ }^{2}$ Cracow University of Technology, Faculty of Mechanical Engineering, Poland

\begin{abstract}
The subject of the presented work was the analysis of the influence of the distance between the electrodes using in the coating process on the tribological properties of oxide coatings. Oxide coatings were prepared on EN AW-5251 aluminum alloy samples. The samples surfaces were subjected to hard anodizing process in a multicomponent electrolyte based on sulfuric acid with an addition of organic acids. Anodizing was carried out with a constant electric charge density of $180 \mathrm{~A} \cdot \mathrm{min} / \mathrm{dm}^{2}$. The distances between the electrodes for subsequent samples increased every 0.125 $\mathrm{m}$ up to $1 \mathrm{~m}$. The tribological partner in a sliding couple with oxide layers was pin of PEEK/BG. Tribological tests were conducted on a T-17 tester in reciprocating motion, in technically dry friction conditions. Before and after tribological test, examination of the geometrical structure of counter-specimens' surface was carried out using the Form Talysurf contact profilographometer, via a 3D method. The most satisfactory tribological parameters were obtained for the PEEK/BG association with the coating produced at a distance between the electrodes equal to $0.25 \mathrm{~m}$.
\end{abstract}

Keywords: anodic oxide coating, distance between electrodes, tribological properties

\section{INTRODUCTION}

The sliding association commonly, which allows to obtain high reliability and durability of devices, are those which cooperate with each other metal-plastic pairs (Friedrich, 2018). Increasingly, oxide coatings produced on aluminum alloys are also used in piston-cylindrical systems. One of example of such application can be an oil-less pneumatic cylinder. The cylinder is made of an aluminum alloy which is hardened internally by anodizing. The polymer ring provides the piston guidance on the cylinder surface (Bara, Służałek and Bąkowski, 2009). During work of such sliding association, the polymeric material is transferred to the cylinder's surface (Kmita and Bara, 2012). The wear of plastic in this type of associations is closely related to the material transfer process and the formation of a polymer sliding film (Korzekwa et al., 2016). Different dimensions of the anodized elements of piston-cylinder systems determine the use of 
various electrode distances in the anodizing process. Changing the distance between the electrodes, in turn, affects the change of the porosity of the coatings, which can cause excessive wear of the polymer ring, and thus decrease in the durability of pistoncylindrical devices.

The purpose of this article is to check how the change in the distance between the electrodes affects the tribological properties of the coatings associated with the popular sliding material.

\section{MATERIALS AND METHODS}

The oxide coatings were produced on the EN AW-5251 aluminum alloy. Samples with an area of $1 \times 10^{-3} \mathrm{~m}^{2}$ were etched in $5 \% \mathrm{KOH}$ solution, and then in a $10 \% \mathrm{HNO}_{3}$ solution before the anodizing process. Anodizing of the surface samples was carried out in an aqueous solution of acids: $\mathrm{H}_{2} \mathrm{SO}_{4}, \mathrm{C}_{2} \mathrm{H}_{2} \mathrm{O}_{4} \cdot 2 \mathrm{H}_{2} \mathrm{O}$. The addition of $\mathrm{C}_{8} \mathrm{H}_{6} \mathrm{O}_{4}$ allows obtaining the hard layers at room temperature. Anodization was carried out using the constant current method using a stabilized GPR-25H30D power supply. The anodizing process was performed for $1 \mathrm{~h}$ at a current density of $3 \mathrm{~A} / \mathrm{dm}^{2}$. The electrolyte temperature was $296 \mathrm{~K}$. The spacing between electrodes from $0.125 \mathrm{~m}$ to $1 \mathrm{~m}$ increased as $0.125 \mathrm{~m}$ for next samples. After anodizing the samples with the $\mathrm{Al}_{2} \mathrm{O}_{3}$ layer were rinsed in distilled water. The produced coatings have showed the surface porosity characteristic for $\mathrm{Al}_{2} \mathrm{O}_{3}$ coatings (Fig. 1a). The tribological partner in the sliding association with oxide coatings was a pin with a diameter of $9 \times 10^{-3} \mathrm{~m}$, made of PEEK/BG plastic. This composite, thanks to the addition of PTFE, graphite and carbon fibers to PEEK (Fig. 1b), provides high mechanical strength, high stiffness and hardness as well as reduced sliding movement resistance, even at higher temperatures (Lu and Friedrich, 1995).

a)

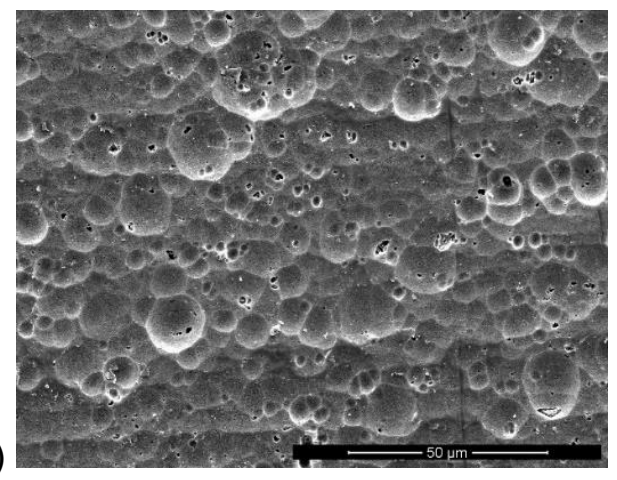

b)

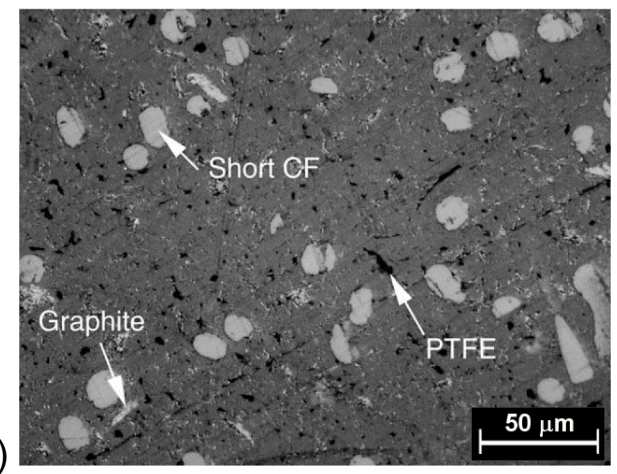

Fig. 1. Image of (a) the surface morphology of the oxide coating,

(b) microstructure of PEEK/BG plastic (Zhang et al., 2004)

The thickness of obtained oxide layers was measured by Dualscope MP40 thickness meter. Ten measurements were made on the length of each sample and the average values were calculated. Tribological tests were conducted on a T-17 tester in reciprocating motion, in technically dry friction conditions. The tests were carried out in ambient temperature of $296 \pm 1 \mathrm{~K}$ at relative humidity of the air of $40 \pm 10 \%$. A constant value of $1 \mathrm{MPa}$ unit pressure and a constant value of average sliding speed, $0.2 \mathrm{~m} / \mathrm{s}$, were applied for all the investigated couples. The tests were conveyed on a 15kilometre path of friction. The friction force was measured by means of Spider 8, analogto-digital converter, using sampling of $50 \mathrm{~Hz}$. The material wear values were determined 
using electronic analytical scales WPA 60 , measuring to an accuracy of $0.1 \mathrm{mg}$. Prior to and after the tribological test, examination of the geometrical structure of samples surface was carried out, using the Form Talysurf contact profilographometer, via a 3D method. Data were analyzed from an area of $2 \times 2 \mathrm{~mm}$, with a sampling step of $2 \mu \mathrm{m}$.

\section{RESULTS AND DISCUSSION}

The thickness of all coatings was about $50 \mu \mathrm{m}$. The thickness measurements of coatings did not show significant differences resulting from the use of different electrode distances (Tab. 1).

Table 1

List of oxide layer thicknesses

\begin{tabular}{|l|c|c|c|c|c|c|c|c|}
\hline $\begin{array}{c}\text { Sample } \\
\text { (distance of } \\
\text { electrodes) }\end{array}$ & $\begin{array}{c}\mathbf{A} \\
\mathbf{0 . 1 2 5} \mathbf{~ m}\end{array}$ & $\mathbf{0 . 2 5} \mathbf{~ \mathbf { ~ }}$ & $\mathbf{0 . 3 7 5} \mathbf{~ \mathbf { ~ }}$ & $\begin{array}{c}\mathbf{0} \\
\mathbf{0 . 5} \mathbf{~ m}\end{array}$ & $\begin{array}{c}\mathbf{E} \\
\mathbf{0 . 6 2 5} \mathbf{~ m}\end{array}$ & $\begin{array}{c}\mathbf{F} \\
\mathbf{0 . 7 5} \mathbf{~ m}\end{array}$ & $\begin{array}{c}\mathbf{G} \\
\mathbf{0 . 8 7 5} \mathbf{~ m}\end{array}$ & $\begin{array}{c}\mathbf{H} \\
\mathbf{~ m}\end{array}$ \\
\hline $\begin{array}{l}\text { Thickness } \\
(\mu \mathrm{m})\end{array}$ & 50.5 & 50.7 & 51.1 & 50.3 & 50.3 & 50.5 & 50.7 & 50.3 \\
\hline $\begin{array}{l}\text { Deviation } \\
(\mu \mathrm{m})\end{array}$ & 0.5 & 0.2 & 0.4 & 0.3 & 0.5 & 0.4 & 0.1 & 0.3 \\
\hline
\end{tabular}

The results of the tribological tests are presented as the friction coefficient (Fig. 2) and wear for the PEEK/BG material (Fig. 3) as a function of the distances between the electrodes in the anodizing process.

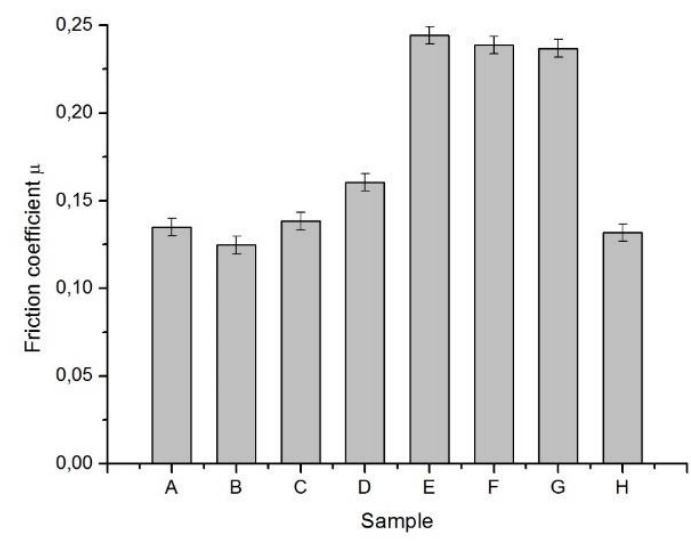

Fig. 2. The influence of the distance between the electrodes in the anodizing process on coefficient of friction

As a result of the tribological tests, in all cases the PEEK/BG material was transferred to the oxide surface. Macroscopic observations showed the influence of the distance between the electrodes in the anodizing process on the creation of the sliding film. Significantly better efficiency of polymer lubrication was obtained for the combination of PEEK/BG material with samples $\mathrm{A}-\mathrm{C}$ and $\mathrm{H}$, sliding film exhibited adequate thickness and good adhesion to the surface of the coatings (Fig. 4a). It was the result of good cooperation of triboelements and resulted in a low value of plastic wear (1.1-5.7 mg). The D-G surfaces exhibited a small covering of the coatings with a sliding film with several adhesions (Fig. 4b), which resulted in the higher value of friction coefficient and plastic wear (11.3 - $50.64 \mathrm{mg}$ ). 


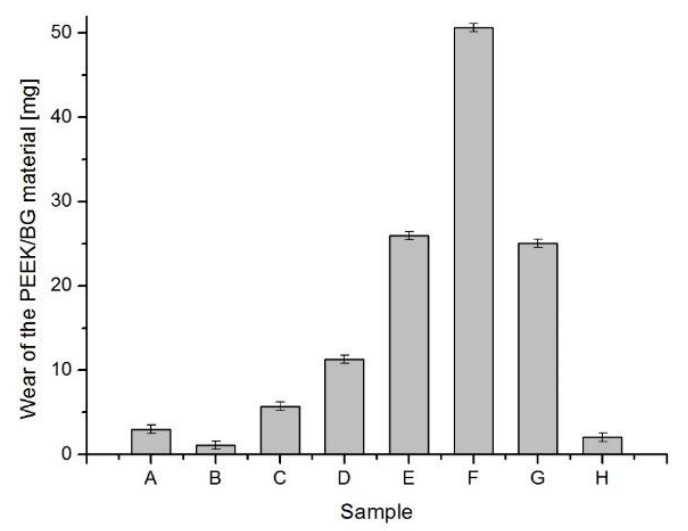

Fig. 3. The influence of the distance between the electrodes in the anodizing process on mass consumption PEEK/BG

The greater wear of PEEK/BG during association with oxide coatings is the result of "dusting of the material" (Fig. 4b).
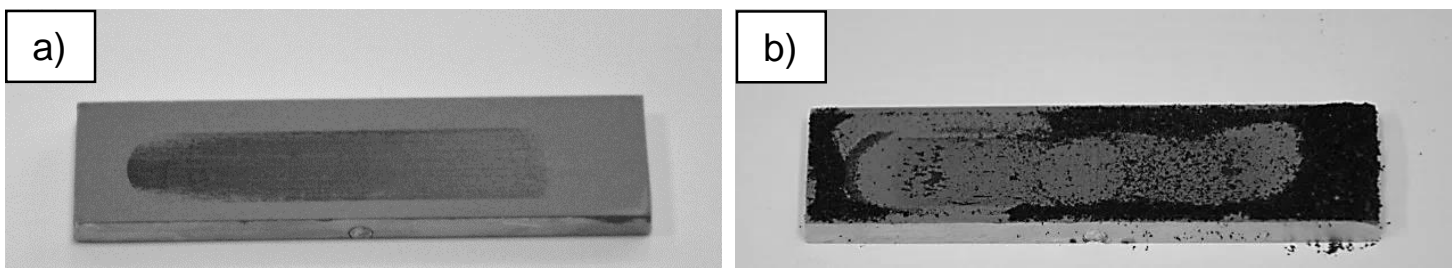

Fig. 4. The oxide coating after a sliding interaction with PEEK/BG: a) sample $B$, b) sample $F$

Stereometric tests of coatings carried out before sliding contact with PEEK/BG plastic did not show major differences in roughness that could affect the results of tribological tests (Table 2). The low values of the Sa parameter show a favorable roughness of the coatings intended for sliding associations with polymeric materials. As a result of tribological tests, there was a slight decrease in the values of coating roughness parameters. Only for the coating produced at the $0.75 \mathrm{~m}$ distance between the electrodes the increased roughness was noticed. The value of Sa parameter increased from 0.52 to 0.59 .

Table 2

Roughness parameters of oxide coatings

\begin{tabular}{|c|c|c|c|c|c|c|c|c|}
\hline $\begin{array}{c}\text { Sample } \\
\text { (distance of } \\
\text { electrodes) }\end{array}$ & $\begin{array}{c}A \\
0.125 \mathrm{~m}\end{array}$ & $\begin{array}{c}\text { B } \\
0.25 \mathrm{~m}\end{array}$ & $\begin{array}{c}C \\
0.375 \mathrm{~m}\end{array}$ & $\begin{array}{c}D \\
0.5 \mathrm{~m}\end{array}$ & $\begin{array}{c}E \\
0.625 \mathrm{~m}\end{array}$ & $\begin{array}{c}F \\
0.75 \mathrm{~m}\end{array}$ & $\begin{array}{c}\mathrm{G} \\
0.875 \mathrm{~m}\end{array}$ & $\begin{array}{c}H \\
1 \mathrm{~m}\end{array}$ \\
\hline $\begin{array}{l}\text { Sa before } \\
\text { the test }(\mu \mathrm{m})\end{array}$ & 0.45 & 0.56 & 0.38 & 0.38 & 0.38 & 0.52 & 0.56 & 0.37 \\
\hline $\begin{array}{l}\text { Sa after the } \\
\text { test }(\mu \mathrm{m})\end{array}$ & 0.36 & 0.44 & 0.29 & 0.29 & 0.30 & 0.59 & 0.48 & 0.30 \\
\hline
\end{tabular}

Changing the tendency to the lower Sa parameter could be caused by small thickness sliding film and adhesions formed on this surface. 


\section{CONCLUSION}

Tribological tests of $\mathrm{Al}_{2} \mathrm{O}_{3}$ coatings in sliding associations with PEEK/BG material showed significant differences in the values of friction coefficient and wear plastic resulting by different technological parameters. The lowest wear value of plastic (1.1 $\mathrm{mg}$ ) was obtained for PEEK/BG association with a coating produced at a $0.25 \mathrm{~m}$ distance between electrodes. For this association, the friction coefficient also had the lowest value (0.12). The PEEK/BG plastic usually has favorable low values of tribological parameters. However, research has shown that the oxide coatings produced at distances of $0.5-0.785 \mathrm{~m}$, due to intensive wear of PEEK/BG plastic, are not suitable for sliding association with this material. The excessive wear of plastic caused by limiting of sorption of the oxide coating most probably resulted from changes in the porosity of the coatings, which interprets into a change in the nature of the sliding association. Coatings produced according to such parameters should not be used in oil-less kinematic piston-cylinder nodes.

Obtained results may be of interest in other areas of materials science e.g. special coatings technology (Pobedza and Sobczyk, 2013; Korzekwa et al., 2018; Radek et al., 2018), even in combustion applications (Opydo et al., 2016) or laser texturization of surfaces (Gadek-Moszczak et al., 2014; Radek et al., 2014). The data analysis methodology, what was used, may be also inspiring in similar investigations focused on material modifications e.g. (Dudek et al., 2010; Lipinski, 2015, Lipinski, 2018; Szczotok et al., 2018), image analysis methods (Gadek-Moszczak and Wojnar, 2009; GadekMoszczak et al., 2015) or even in museum revitalization of old military equipment (Karpisz and Kielbus, 2019), where the original noise level produced by kinematic pairs is unacceptable. Finally, the results should be widely disseminated in scientific and industrial databases (Gawlik et al., 2015).

\section{REFERENCES}

Bara, M., Służałek, G., Bakowski, H., 2009. Determination of the distribution of stresses and temperature in the pneumatic servo-motor with a ceramic cylinder bearing surface, using FEM, 13th International Conference Computer Systems Aided Science, Industry and Transport "TRANSCOMP 2009", Zakopane, Logistyka, 6, 1-8 CD.

Dudek, A., Wlodarczyk, R., Nitkiewicz, Z., 2010. Structural analysis of sintered materials used for low-temperature fuel cell plates. Materials Science Forum, 638642, 536-541. DOI: 10.4028/www.scientific.net/MSF.638-642.536

Friedrich, K., 2018. Polymer composites for tribological applications, Advanced Industrial and Engineering Polymer Research, 1, 3-39. DOI: 10.1016/j.aiepr.2018.05.001

Gadek-Moszczak, A., Pietraszek, J., Jasiewicz, B., Sikorska, S., Wojnar, L., 2015. The bootstrap approach to the comparison of two methods applied to the evaluation of the growth index in the analysis of the digital $x$-ray image of a bone regenerate. New Trends in Comput. Collective Intell., 572, 127-136. DOI: 10.1007/978-3-319-107745_12Comput. Collective Intell., 2015, vol. 572, pp.127-136.

Gadek-Moszczak, A., Radek, N., Wronski, S., Tarasiuk, J., 2014. Application the 3D image analysis techniques for assessment the quality of material surface layer before and after laser treatment. Adv. Mat. Res. Switz., 874, 133-138. DOI: 10.4028/www.scientific.net/AMR.874.133 
Gadek-Moszczak, A., Wojnar, L. 2009. Objective, quantitative and automatic $x$-ray image analysis of the bone regenerate in the ilizarov method. ECS10: The 10 European Congress of Stereology and Image Analysis, Milan, Int. Society for Stereology, 453-458.

Gawlik, J., Kielbus, A., Karpisz, D., 2015. Application of an integrated database system for processing difficult material. Solid State Phenomena, 223, 35-45. DOI: 10.4028/www.scientific.net/SSP.223.35

Karpisz, D., Kielbus, A., 2019. The Revitalization of Radar System as a Case of Functional and Information Security Problems. System Safety: Human - Technical Facility - Environment, 1, 692-699. DOI: 10.2478/czoto-2019-0088

Kmita, T., Bara, M., 2012. Surface oxide layers with an increased carbon content for applications in oil-less tribological systems. Chemical and Process EngineeringInzynieria Chemiczna i Procesowa, 33, 479-486. DOI: 10.2478/v10176-012-0040-z

Korzekwa, J., Bara, M., Pietraszek, J., Pawlus, P., 2016. Tribological behaviour of $\mathrm{Al}_{2} \mathrm{O}_{3}$ /inorganic fullerene-like $\mathrm{WS}_{2}$ composite layer sliding against plastic, International Journal of Surface Science and Engineering, 10, 570-584. DOI: 10.1504/IJSURFSE.2016.10001964

Korzekwa, J., Gadek-Moszczak, A., Zubko, M., 2018. Influence of the size of nanoparticles on the microstructure of oxide coatings. Materials Science, 53, 709716. DOI: 10.1007/s11003-018-0127-x

Lipinski, T., 2015. Double modification of AISigMg alloy with boron, titanium and strontium. Arch. Metall. Mater., 60, 2415-2419. DOI: 10.1515/amm-2015-0394

Lipinski, T., 2018. The effect of the diameter and spacing between impurities on the fatigue strength coefficient of structural steel. Arch. Metall. Mater., 63, 519-524. DOI: $10.24425 / 118970$

Lu, Z. P., Friedrich, K., 1995. On sliding friction and wear of PEEK and its composites, Wear, 181-183, 624-631.

Opydo, M., Kobylecki, R., Dudek, A., Bis, Z. 2016. The effect of biomass co-combustion in a CFB boiler on solids accumulation on surfaces of P91 steel tube samples. Biomass \& Bioenergy, 85, 61-68. DOI: 10.1016/j.biombioe.2015.12.011

Pobedza, J., Sobczyk, A., 2013. Modern Coating Used in High Pressure Water Hydraulic Components. Key Engineering Materials, 542, 143-155. DOI: 10.4028/www.scientific.net/KEM.542.143

Radek, N., Pietraszek, J., Antoszewski, B., 2014. The Average Friction Coefficient of Laser Textured Surfaces of Silicon Carbide Identified by RSM Methodology. Adv. Mat. Res.-Switz., 874, 29-34. DOI: 10.4028/www.scientific.net/AMR.874.29

Radek, N., Szczotok, A., Gadek-Moszczak, A., Dwornicka, R., Broncek, J., Pietraszek, J., 2018. The impact of laser processing parameters on the properties of electrospark deposited coatings. Arch. Metall. Mater., 63, 809-816. DOI: 10.24425/122407

Szczotok, A., Radek, N., Dwornicka, R., 2018. Effect of the induction hardening on microstructures of the selected steels. METAL 2018: $27^{\text {th }}$ Int. Conf. Metallurgy and Materials. Ostrava, Tanger, 1264-1269.

Zhang, Z., Breidt, C., Chang, L., Friedrich, K., 2004. Wear of PEEK composites related to their mechanical performances, Tribology International, 37, 271-277. DOI: 10.1016/j.triboint.2003.09.005 